\title{
The importance of disaggregated freight flow forecasts to inform transport infrastructure investments
}

\author{
Authors: \\ Jan H. Havenga ${ }^{1}$ \\ Affiliations: \\ ${ }^{1}$ Department of Logistics, \\ University of Stellenbosch, \\ South Africa \\ Correspondence to: \\ Jan Havenga \\ Email: \\ janh@sun.ac.za

\section{Postal address:} \\ Department of Logistics, \\ University of Stellenbosch, \\ Private Bag X1, 7602, \\ Matieland, South Africa \\ Dates: \\ Received: 19 June 2013 \\ Accepted: 06 Aug. 2013 \\ Published: 20 Sept. 2013 \\ How to cite this article: \\ Havenga, J.H., 2013, 'The \\ importance of disaggregated \\ freight flow forecasts \\ to inform transport \\ infrastructure investments', \\ Journal of Transport and \\ Supply Chain Management \\ 7(1), Art. \#106, 7 pages. \\ http://dx.doi.org/10.4102/
} jtscm.v7i1.106

\section{Copyright:}

(C) 2013. The Authors. Licensee: AOSIS OpenJournals. This work is licensed under the Creative Commons Attribution License.
Read online:
This article presents the results of a comprehensive disaggregated commodity flow model for South Africa. The wealth of data available enables a segmented analysis of future freight transportation demand in order to assist with the prioritisation of transportation investments, the development of transport policy and the growth of the logistics service provider industry. In 2011, economic demand for commodities in South Africa's competitive surface-freight transport market amounted to 622 million tons and is predicted to increase to $1834 \mathrm{~m}$ tons by 2041, which is a compound annual growth rate of $3.67 \%$. Fifty percent of corridor freight constitutes break bulk; intermodal solutions are therefore critical in South Africa. Scenario analysis indicates that $80 \%$ of corridor break-bulk tons can by serviced by four intermodal facilities - in Gauteng, Durban, Cape Town and Port Elizabeth. This would allow for the development of an investment planning hierarchy, enable industry targeting (through commodity visibility), ensure capacity development ahead of demand and lower the cost of logistics in South Africa.

\section{Introduction}

South Africa's cost of logistics in relation to the gross domestic product (GDP) declined from $14.7 \%$ in 2008 to $13.5 \%$ in 2009 (Havenga, Pienaar \& Simpson 2011), but it is still higher than in many developed economies (such as the USA, Japan and Singapore) where it is between $8.0 \%-10.0 \%$ of the GDP (Rantasila \& Ojala 2012). South Africa's disproportionate long-distance road-freight transport market share is a key contributor to this state of affairs; this is due to the resulting increased exposure to volatile fuel prices driven mainly by exchange rates and oil prices (Havenga et al. 2011). A prerequisite for reducing this exposure is a more in-depth understanding of the freight transport market through access to reliable, disaggregated freight flow information in order to inform public freight transport infrastructure investment planning (Black 1998; Schwarm, Jackson \& Okuyama 2006; Lyk-Jensen 2011). Freight forecasting is also a critical input for broader policy making efforts such as macroeconomic growth, land use and environmental externalities (Curlee 2006).

The survey methodology for quantifying freight flows has yielded very poor results in South Africa (Havenga \& Pienaar 2012a). South Africa's national freight-flow model (NFFM), which was based on truck movement observations, was developed in 2004 to define the core configuration of South Africa's freight transport system (Havenga 2007; Havenga \& Pienaar 2012b). However, these flows were for total freight, with no indication of the commodity composition (which is not possible given the methodology). In addition, geographical information was limited. A commodity flow model (CFM) utilising a gravity-based flow estimation was therefore developed for South Africa to supplement the NFFM. The relevance of commodity flows in freight transport demand analysis is discussed in the next section, followed by a description of the CFM research methodology, a discussion of the research results and concluding remarks.

\section{Commodity flows in freight transport demand analysis: Practical applications Economic applications: Regional economic and infrastructural linkages}

The efficient movement of freight is vital for growth and economic development (Harris \& Anderson 2011). A prerequisite for efficient freight movement is transportation planning, which must be based on regional commodity-level transport demand models to inform the demand for regional transportation facilities and services (Mesenbourg 2011). It also informs the role of shared regional infrastructure by providing a measure of the extent to which industries in different regions are linked and the potential reciprocal impact of policy and investment decisions (Zhang et al. 2003; Schwarm et al. 2006; Richard Paling Consulting 2008).

In the USA, results from the commodity flow survey (CFS) were, for example, applied to explore the feasibility of dedicated truck lanes. The CFS's flow summaries and map outputs allowed 
the visualisation of directional proportional flow volumes in terms of value and tonnage, by commodity, mode and combinations thereof (Digre, Berndt \& Bingham 2011). In addition, knowledge regarding bi-directional flows informs decisions by logistics service providers regarding dedicated truck fleets for certain industries (Panchalavarapu 2010). Regional commodity flow matrices result in a deep understanding of the economic and industrial base of a region; this is a prerequisite for estimating future freight flows since the sectoral impact of changes in economic conditions and the concomitant impact on freight transport demand can be modelled more accurately (Harris \& Anderson 2011; Mesenbourg 2011; Lawson, Nampoothiri \& Peters 2011). Given the scale and relative permanency of large-scale infrastructure investments in a resource-challenged world, the benefit of improved accuracy is evident (Havenga 2007).

\section{Transport planning and policy: Investing for optimal modal balance}

Commodity-level data enables an understanding of current modal shares, the sustainability of future freight flows given the current trajectories and where to target modal shift given commodity characteristics (Lyk-Jensen 2011). Zhang et al. (2003) reported on the development of a methodology, based on the CFS data, to systematically estimate state-wide truck travel demand using the state of Mississippi as a case study. The objective is inter alia to identify and prioritise intermodal infrastructure opportunities given that highway networks are experiencing severe congestion (with concomitant externality costs), whilst other surface transportation modes are under-utilised. Similarly, the State of Alabama used the CFS to develop a state-wide intermodal model that showed the possible impact of newly relocated industries and the movement of their goods on the state's existing transportation infrastructure. Understanding the total characteristics of freight movements along a corridor - its prevalent commodities and potential safety and operational constraints - facilitates the identification of potential options for shifting commodities to alternate modes of transport to alleviate congestion (Anderson \& Harris 2011).

\section{Industry-specific applications}

Commodity-level analysis enables freight activity to be linked with underlying economic activity, such as the increase in high-value, low-weight products that inform modal, service and transport technology requirements. The establishment of such a dataset would make it possible to link a variety of existing freight and economic data to create a more robust understanding of freight activities (Mesenbourg 2011; Lawson et al. 2011). Key differences are observed between the transportation of lower value, higher value, and hazardous goods, and are discussed below.

Production of low-value bulk commodities such as grain or coal, generate a transport demand disproportionate to their value (Transportation Research Board 1997). For these goods, transport costs can represent a high proportion of the delivered costs. Minimising the transport costs is therefore an essential part of keeping the overall costs low, and for items that are converted into exports, ensuring that they are competitive in world markets (Richard Paling Consulting 2008).

The CFS in the USA has allowed policy makers and researchers to understand how the growth in demand for higher-value and time-sensitive commodities has affected the transportation system by driving growth in trucking (Ludlow 2011). For example, from 1999-2009 the percentage of electronic commerce sales in the retail sector increased sevenfold from $0.6 \%$ of total retail sales in 1999 to $4.1 \%$ in 2009. In manufacturing, e-commerce shipments increased from $18.0 \%$ of total manufacturing shipments in 2000, to 39.0\% in 2008 (Mesenbourg 2011; Lawson et al. 2011). The CFS has also been applied to understand the impact of increasing globalisation on furniture-industry supply chains, with US furniture imports having grown by $107.7 \%$ and exports having increased by $40.4 \%$ from 1999-2007 (Liu \& Tolliver 2011).

An understanding of the transportation of hazardous materials allows objective evaluation of the safety risks involved. Understanding the geographical flows of these commodities facilitates policy-making, alleviates public safety concerns by providing data for conducting risk analyses and security assessments, and identifies emergency response and 'preparedness requirements' (Duych 2011).

\section{Research methodology Supply and demand per commodity on a geographical basis}

The modelling of supply (production and imports) and demand (intermediate demand, final demand, exports and inventory investments) on a geographical basis per commodity is based on the input-output table (I-O table) of the economy. The I-O table quantifies all transactions that take place between the main economic sectors in a particular year. Thus, by its nature, the I-O table gives detailed information on the intermediate and final demand components of each commodity in the economy (Mullins 1977; De Jong, Gunn \& Walker 2004; McDonald \& Punt 2005). The modelling of total supply and demand addresses a concern raised by LykJensen (2011) that freight traffic forecasting typically does not adequately incorporate international trade flows.

The supply and demand data from which freight flows are derived are the end result of work initiated by Mullins (1977) and are based on the following steps: the establishment of a base year I-O table according to commodity on a national level for the six aforementioned supply and demand components; forecasting the I-O tables yearly for the first five years and then at five-year intervals up to 30 years; conversion of the monetary I-O tables into volumetric terms and disaggregating these national figures on a magisterial district (MD) basis. The simultaneous sectorial and geographical division of an economy enables inter-regional analysis in order to determine inter-industry linkages between areas 
(Smith 1970). The forecast tables (which are always in real terms and exclude future expected inflation, even though the effect of expected inflation on real-term growth is one of the considerations when forecasting) are used to generate growth rates. The growth rates are applied to the base tables, which are already converted to tons. The generated forecast tables therefore exclude inflation and standard commodity price increases. The exact same approach holds for exchange rate fluctuations. The translation is done based on the Standard Industrial Classification system that includes various measurement units such as litres for fuel and cubic metres for wood. These units are translated into tons, based on standard volume and density measures.

\section{Estimation of flows per commodity}

The estimation of commodity flows is based on gravity modelling using the volumetric MD supply and demand data from the I-O process. Gravity modellling is the most widely used approach internationally to distribute freight flows between origins and destinations and has been operationalised in various international freight flow models (Raha \& Williams 2002:38-40; RAND Europe 2001:7; LykJensen 2011). Gravity modelling is based on the premise that freight flows between origins and destinations are determined by supply and demand, and are a measure of transport resistance (Krygsman 2006; Lyk-Jensen 2011). For the purposes of this research, the transport resistance measure used was a distance decay function, a common proxy for transport cost (Smith 1970; Black 1998). Whilst the I-O model provides data for the 356 MDs in South Africa, the gravity model expands this to 372 regions by distinguishing the eight border posts between South Africa and its neighbouring countries, South Africa's seven ocean ports, and its largest freight airport.

The input data for flow modelling is created by subtracting the origin and destination data of known flows (rail, pipeline, conveyor and coastal shipping) from the supply (origin) and demand (destination) values; the balance of flows is modelled on origins and destinations. The decay factor is added for each commodity. The CFM then estimates road freight flows in tons and ton-kilometres in South Africa (summarised into 64 commodity groups) between the 372 regions, with 30-year forecasts and for three growth scenarios; it results in more than one million records of freight-flow data between defined origin and destination pairs. Known rail flows are utilised to conduct detailed modal analysis. Road and rail are the two competitive surface freight transport modes in South Africa - there are no waterways and coastal shipping is negligible. The CFM is refined and updated annually.

\section{Freight transport typologies}

Surface freight transport can be classified into four distinct typologies. The salient characteristics of each typology are compared in Table 1.

The primary typology refers to ring-fenced logistics systems that are, by nature, mode-monopolistic with known flows, and falls outside of the scope of this article. The competitive surface freight transport market refers to corridor, metropolitan ${ }^{1}$ and rural freight typologies.

\section{Key success factors of South Africa's commodity flow model}

The key success factors of South Africa's CFM are:

- its unique geographical and commodity granularity as compared to a range of models discussed in De Jong et al. (2004); Zhang et al. (2003); and Sprung et al. (2011)

- classification of all input data according to the SIC to avoid data comparability issues (as described in Harris \& Anderson 2011)

- the availability of actual disaggregated rail flows per MD and commodity that eliminates challenges regarding modal allocations (refer to Zhang et al. 2003; Black 1998; and Richard Paling Consulting 2008).

\section{Results}

\section{Growth in economic demand for commodities}

In 2011, economic demand for commodities in South Africa's competitive surface-freight transport market (refer to definition in methodology) amounted to $622 \mathrm{~m}$ tons. It is predicted that this will increase to $1834 \mathrm{~m}$ tons by 2041, which

1.Metropolitan freight is an important typology when freight flows in general is considered. A very small portion is, however, rail friendly and is picked up by this methodology. This will be explained later.

TABLE 1: Definition of transport typologies.

\begin{tabular}{|c|c|c|c|c|}
\hline \multirow[t]{2}{*}{ Item } & \multicolumn{4}{|c|}{ Transport typologies } \\
\hline & Primary & Corridor & Rural & Metropolitan \\
\hline Traffic type & $\begin{array}{l}\text { Bulk, low-value } \\
\text { (ring-fenced rail-export coal and iron } \\
\text { ore; conveyor belt coal; pipelines) }\end{array}$ & $\begin{array}{l}\text { Higher value, mostly } \\
\text { manufacturing }\end{array}$ & Mostly agriculture & Mostly final delivery \\
\hline Distance & Long and short & Long and short & Medium and short & Short \\
\hline $\begin{array}{l}\text { Origin destination } \\
\text { (OD) pairs }\end{array}$ & Few, usually one-directional & $\begin{array}{l}\text { Few long distance ODs; Many } \\
\text { ODs at end-points }\end{array}$ & Many & Many \\
\hline Major challenge & $\begin{array}{l}\text { Global competitiveness } \\
\text { (export coal and iron ore); energy } \\
\text { sustainability }\end{array}$ & $\begin{array}{l}\text { Spatial organisation, } \\
\text { efficiency }\end{array}$ & Development & Congestion alleviation \\
\hline Ideal logistics approach & Ring-fenced systems & Intermodal solutions & Effective road feeder system & $\begin{array}{l}\text { World-class commuter systems } \\
\text { and effective freight delivery }\end{array}$ \\
\hline
\end{tabular}

Note: this table is based on Van Eeden, J. \& Havenga, J.H., 2010, 'Identification of key target markets for intermodal freight transport solutions in South Africa', Journal of Transport and Supply Chain Management 4(1), 255-267.

$\mathrm{OD}$, Origin-destination 
is a compound annual growth rate (CAGR) of $3.67 \%$ (for an analysis of a comparison between this result and previous approximations see the endnote). Economic growth is usually measured in monetary terms but for the purposes of freight flow measurement the weight or mass of commodities (volume) is important. The economy is expected to grow the fastest in volume in basic earthworks, building-related, food and basic energy-related commodities (Figure 1).

The demand for commodities can also be depicted by showing the growth in tons, excluding coal. Coal is mostly used by mine-fed industries (i.e. short-distance transport) for electricity, and for conversion to fuel and other chemicals; due to its volume dominance, it distorts weight comparisons. When this tonnage growth (excluding coal) is expressed in percentage terms, growth in beneficiated (manufactured) products is expected to be far greater than in un-beneficiated (raw minerals and agricultural) commodities (Figure 2).

\section{Transport demand}

In 2011, the $622 \mathrm{~m}$ tons economic demand for commodities in South Africa's competitive surface freight transport market translated into a transport demand of 178 billion tonkilometres. Tonkilometre is the standard unit for measuring freight transport, as it takes into account both tons and distance travelled (Chasomeris 2003:133). Almost two thirds of this transport is delivered over long-distance corridors, and one third is delivered in rural areas (i.e. is not on corridors) (Figure 3). The CFM does not account for final distribution or redistribution and therefore cannot accurately reflect metropolitan transport. Subsequent research should entail collaboration with metropolitan spatial planning modellers to extend the CFM to this level. Even so, metropolitan tons account for almost $20 \%$ of total tons in the CFM (the low tonkilometre contribution is due to the very short distances), already pointing to the congestion facing the metropolitan areas.

Almost a quarter of ton-kilometre demand is from the fast moving consumer goods (FMCG) industries; this is expected to decline to a fifth by 2041. This is followed by transport demand from energy industries, other manufacturing and other agricultural industries, each contributing to about one sixth of demand (Figure 4). FMCG includes beverages, foods, pharmaceuticals, textiles and tobacco. Energy industries include coal, fuels and natural gas. Other manufacturing and other agricultural industries are the remainder of these industries, which are not listed separately in Figure 4.

Road corridor transport contributes $57 \%$ of total tonkilometres and $89 \%$ of corridor ton-kilometres, this results in corridor logistics costs contributing to almost three quarters of logistics costs (Figure 3 and Figure 5). In addition, at $548 \mathrm{~km}$, road corridor average transport distance (ATD) significantly outperforms the rail corridor ATD of $401 \mathrm{~km}$.

\section{Characteristics of corridor freight}

It is predicted that total corridor freight will grow by $182 \%$ between 2011 and 2041. Of this growth, 45\% will occur on

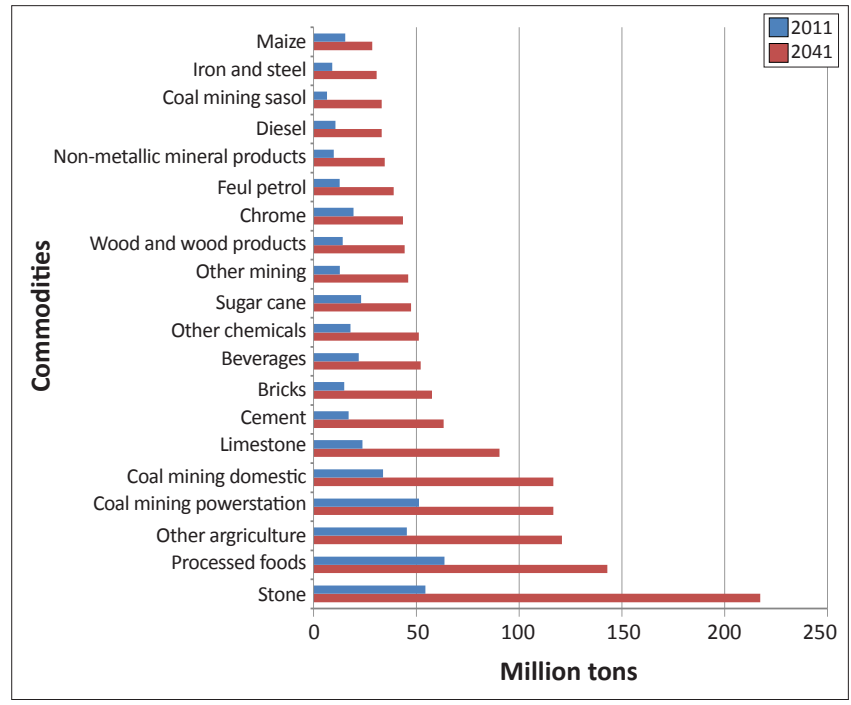

FIGURE 1: Top 20 commodities by absolute tonnage growth 2011-2041.

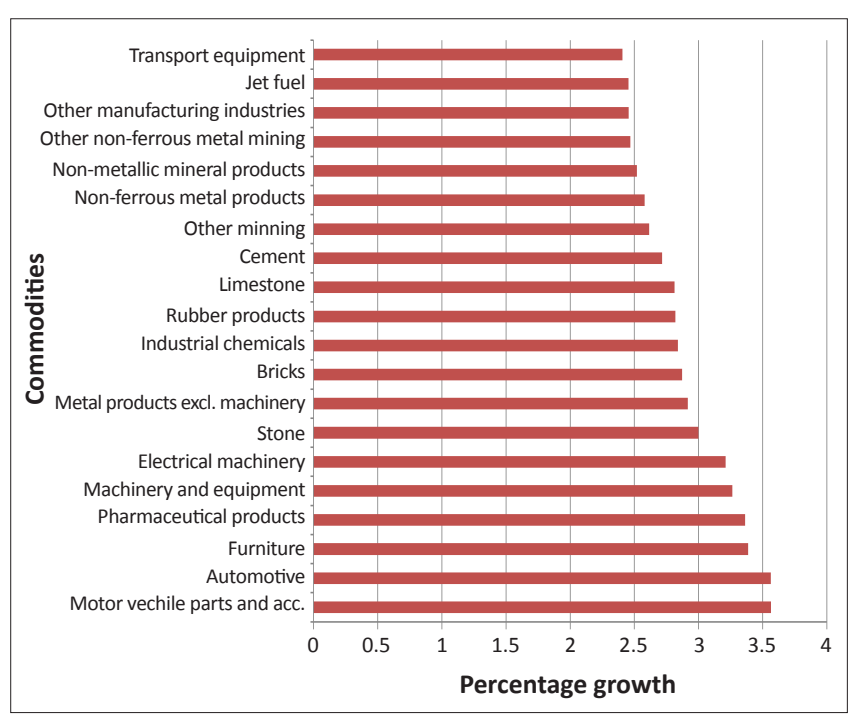

excl., excluding; acc., accessories.

FIGURE 2: Top 20 commodities by percentage tonnage growth 2011-2041.

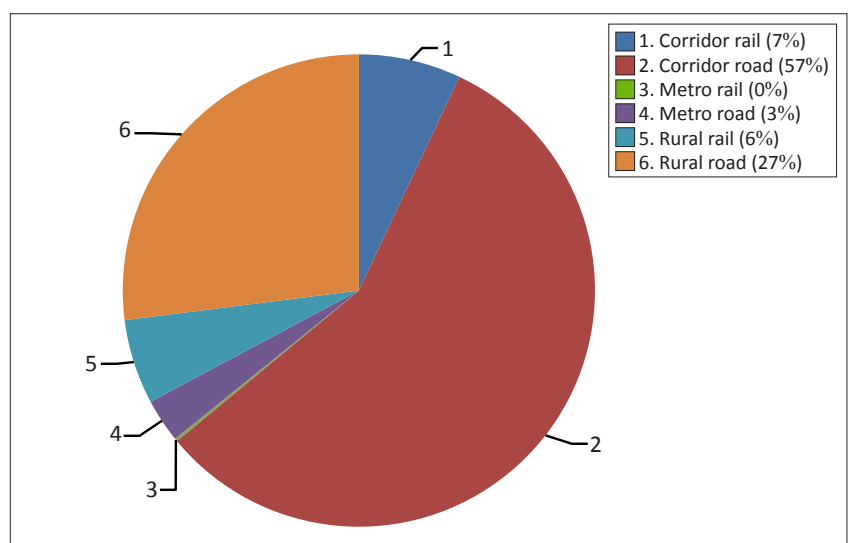

FIGURE 3: Road and rail ton-kilometre contribution to competitive typologies (2011).

the two largest corridors and will continue to do so during the forecast horizon if changes in the current spatial structure of the economy are not engineered over the medium to long term (Figure 6). This supports the construction of a high- 


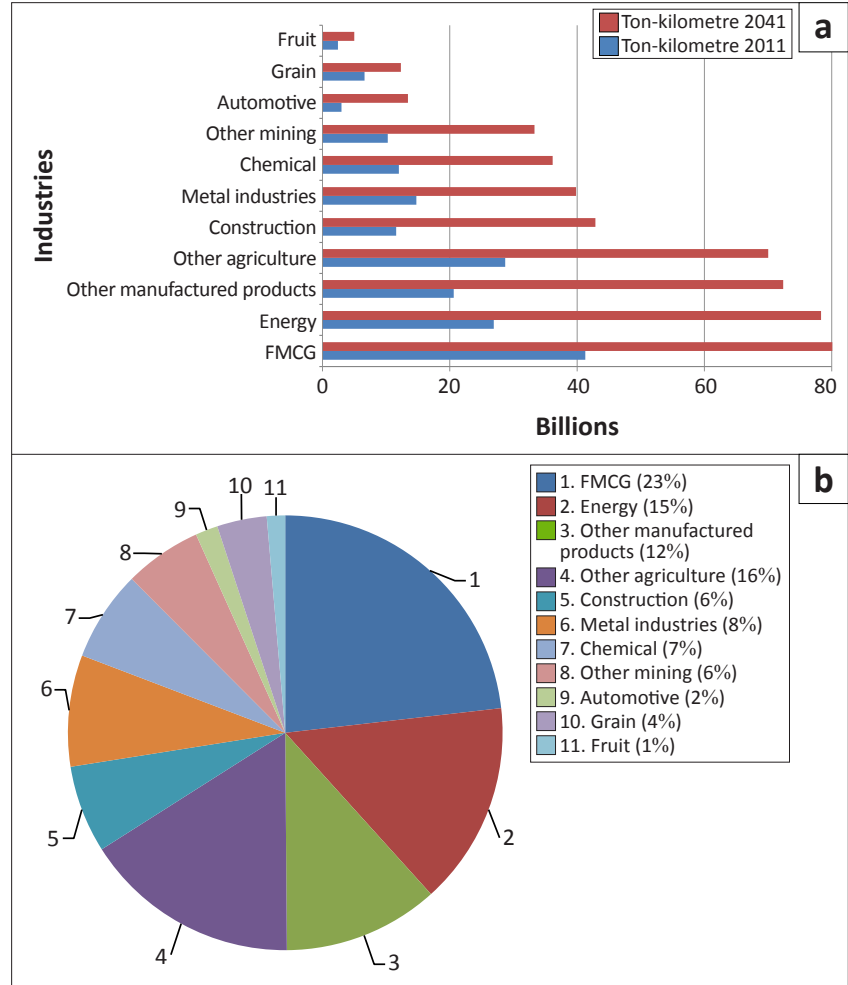

FMCG, fast moving consumer goods

FIGURE 4: Growth in industry ton-kilometre demand 2011-2041 (a) 2011 vs 2041 and (b) 2011 only.

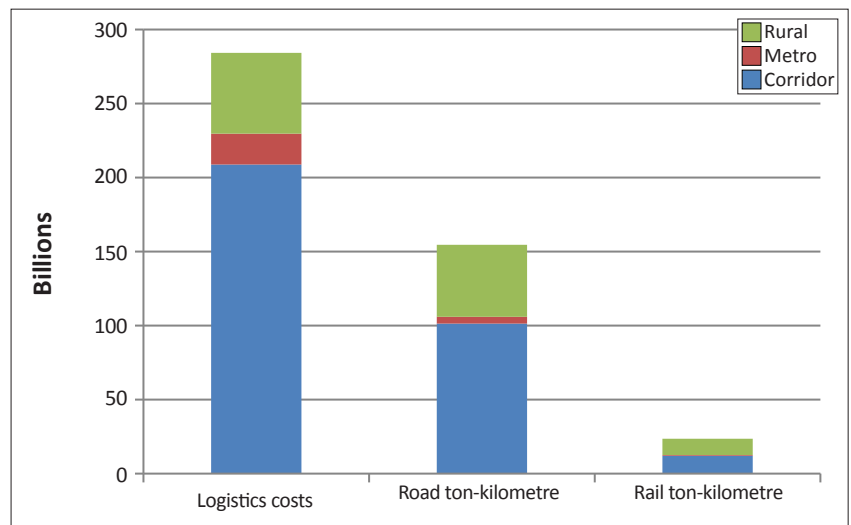

FIGURE 5: Competitive typology magnitude in logistics costs and ton-kilometre (2011).

density core network, which will reduce unit transport costs and allow for investment focus. The forecasted demand suggests that it will be practically impossible to provide the infrastructure that the economy will need if the current rail or road configuration is not improved. Even by tripling the current rail supply, road volumes will have to increase by $180 \%$ on average to meet the demand in 2041 - this is clearly not viable given road logistics and externality cost realities (Havenga et al. 2011).

Therefore, it must be a prority to find sustainable solutions with which to address the challenges of the growth in corridor freight. The depth of information available in the commodity flow model allows for the segmentation of freight on these corridors. This will facilitate stakeholder engagement and the development of policies and logistics solutions to address the

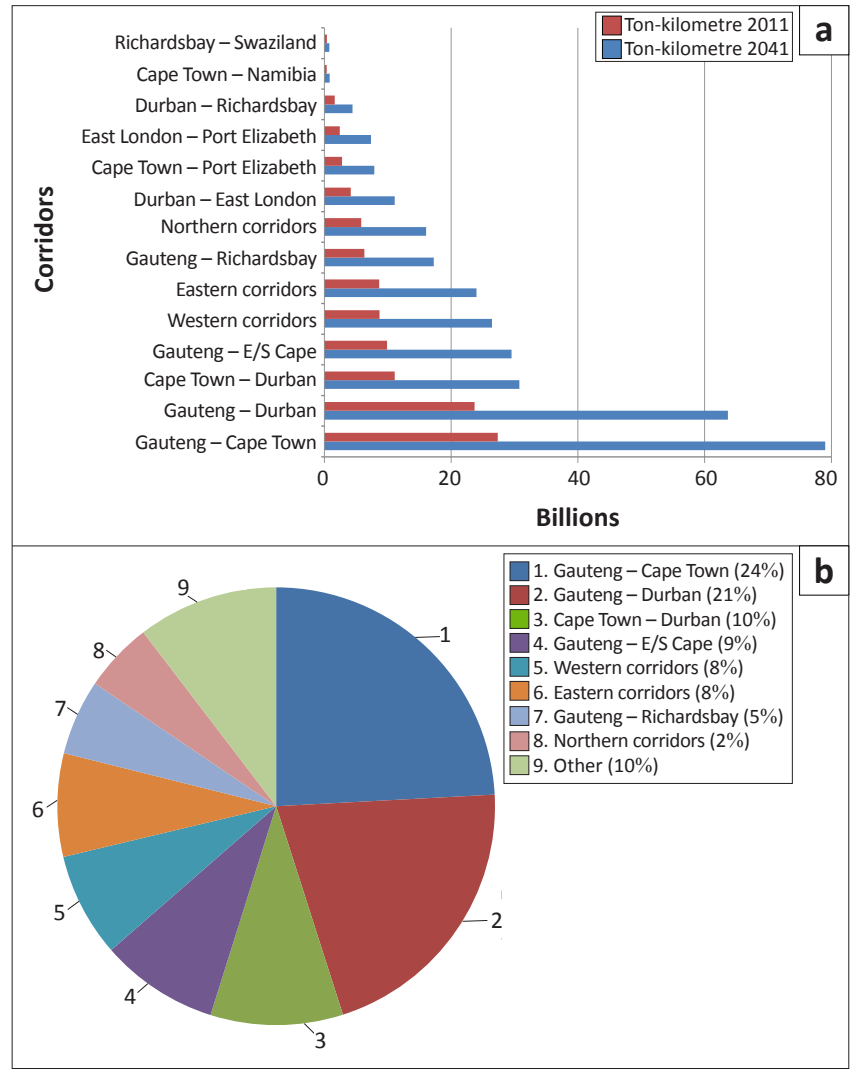

$E / S$, Eastern/Southern.

FIGURE 6: Corridor growth and relative current size (a) 2011 vs 2041 and (b) 2011 only.

disproportionate corridor logistics costs. Half of the corridor freight consists of break bulk, this will triple by 2041, whilst dry bulk contributes to a third, with similar growth prospects (Figure 7). The model indicates that approximately $45 \%$ of the break bulk cargo is already palletised.

In international trade, it is estimated that about $80 \%$ of break bulk cargo moves in containers (Global Security 2013); the penetration rate for all cargo was calculated by Sooredo (2012) to be $66 \%$. The propensity to use containers will increase over the next 20 years; this will lead to an even faster growth in traffic that can easily use intermodal facilities. This situation clearly points the way towards an intermodal strategy and the availability of intermodal facilities where break bulk reaches critical densities, as discussed in the next section.

\section{Scenario: Intermodal freight facilities for South Africa}

Critical densities for intermodal facilities are deemed to be four million tons of break bulk on any corridor longer than 500 km (Van Eeden \& Havenga 2010; Havenga 2012). A scenario was developed for South Africa in order to determine how much freight will be connected by intermodal facilities through a network of connections as each new node in the network is commissioned. The analysis was based on terminal density in Gauteng - it was done in declining order of the weight of freight arriving and departing from Gauteng for each node by weight, as $82 \%$ of corridor freight originates from, terminates in or travels through Gauteng. 


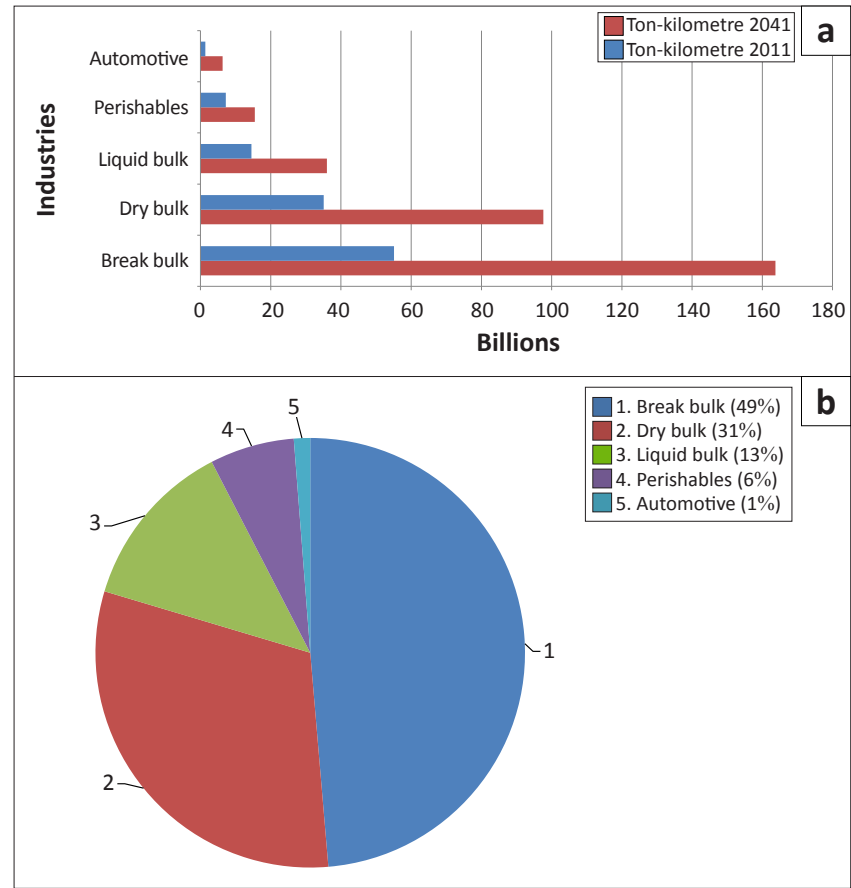

FIGURE 7: Corridor freight demand growth and relative size per packaging type (a) 2011 vs 2041 and (b) 2011 only.

TABLE 2: Cumulative intermodal facilities with Gauteng as intermodal hub.

\begin{tabular}{llll}
\hline Million tons & $\mathbf{2 0 1 1}$ & $\mathbf{2 0 4 1}$ & Cumulative (\%) 2041 tons \\
\hline Durban & 25 & 71 & 42 \\
+ Cape Town & 43 & 123 & 73 \\
+ Port Elizabeth & 46 & 133 & 80 \\
+ Witbank & 49 & 143 & 85 \\
+ Beitbridge & 51 & 150 & 89 \\
+ Upington & 54 & 156 & 93 \\
+ Maputo & 56 & 163 & 97 \\
+ East London & 58 & 168 & 100 \\
\hline
\end{tabular}

+ , denotes cumulative values in rank order, thus for +Cape Town it means the Cape Town value is added to the Durban value to get a new total and +Port Elizabeth then means that the Port Elizabeth value is added to this, etc.

The data indicate that $80 \%$ of corridor break-bulk tons can by serviced by the intermodal facilities in Gauteng, Durban, Cape Town and Port Elizabeth. The commodity flow model analysis therefore allows for the development of an investment-planning hierarchy and enables targeting of stakeholders for investment planning and freight-logistics solution development. For example, in 2041, processed foods and chemicals will amount to $44 \%$ of break bulk freight on the two largest corridors - Gauteng to Durban and Gauteng to Cape Town. These two industries will therefore form the cornerstone of development of intermodal solutions in South Africa. In addition, the model predicts that the bi-directional flow of these two commodities on the Gauteng to Cape Town corridor will be as close to a perfect balance in 2041 , with approximately $14 \mathrm{~m}$ tons flowing in both directions. Nineteen million tons of processed foods and chemicals will flow between Durban and Gauteng in 2041, and eight million tons in the opposite direction. This density of two commodity groups on two corridors, and a very balanced bidirectional flow that is connected at a single high-volume node (Gauteng), makes a clear and unambiguous case for the development of domestic intermodal solutions.

\section{Concluding remarks}

South Africa has one of the most disaggregated commodity flow models in the world. The availability of future transport demand on a commodity level informs strategy in an objective way - through intelligence of location and size requirements of long-term freight logistics infrastructure investment decisions. The model results indicate that $50 \%$ of corridor freight constitutes break bulk. Internationally, about $80 \%$ of break bulk cargo moves in containers; intermodal solutions are therefore a key solution for South Africa's freight demand challenges. Scenario analysis further indicates that $80 \%$ of corridor break-bulk tons can be serviced by only four intermodal facilities - Gauteng, Durban, Cape Town and Port Elizabeth. In addition, the ability to identify target industries based on commodity flows enables collaboration between government (through the state-owned national rail and port operator), industry and logistics service providers to facilitate these infrastructure investments. For example, in 2041, it is predicted that processed foods and chemicals will amount to $44 \%$ of break bulk freight on the two largest corridors: Gauteng to Durban and Gauteng to Cape Town. These two industries will therefore form the cornerstone of development of intermodal solutions in South Africa.

\section{Endnote}

Havenga and Pienaar (2012a) provided a detailed analysis of all attempts to measure surface-freight volumes and road and rail market share in the previous century. They included the pioneering work of Verburgh (1958) up to the Freight Data Bank Report (Pretorius 1991) of the Rand Afrikaanse University (The University of Johannesburg today). Based on the time series that was developed from disparate surveys over 50 years it would seem that the $648 \mathrm{~m}$ tons reported by Pretorius in 1991 was plausible, and that the CFM measurement was too low. Some important differences need to be noted though.

Most surveys in South Africa, prior to the development of a freight flow model based on traffic counts (Havenga \& Pienaar 2012b), were based on a survey of freight owners. McKinnon and Leonardi (2008) reported on the differences between traffic count measurements and the United Kingdom's continuous survey of road transport goods - they found a $29 \%$ difference for various reasons. An input-output based gravity model for the United Kingdom is not available, but in his report on $\mathrm{CO} 2$ emissions from freight transport, Mckinnon (2007) also referred to the United Kingdom's Environmental Accounts (UKEA), which are used to measure emissions together with traffic counts and surveys. The UKEA are satellite accounts from the Office for National Statistics (based on the same broad principles as the CFM); therefore a comparison between the UKEA measurements and the survey and counting methodologies are a valid background and reference point for possible differences in South Africa. The UKEA's measurement of emissions from road freight transport in the United Kingdom was just over $15 \mathrm{~m}$ tons of $\mathrm{CO}_{2}$ in 1990. The measurements recorded 
through surveys were higher (just over $20 \mathrm{~m}$ tons) and from traffic counts even higher (just over $25 \mathrm{~m}$ tons). These gaps are comparable with the South African situation, where the CFM measurement is the lowest; Pretorius' assumed measurement (if the methodology were to be applied today) is higher; and the traffic count survey of Havenga and Pienaar is even higher. The United Kingdom's gap between these surveys is shrinking, but was still $25 \%$ in 2006. More research is required as to the reasons for these differences.

\section{Acknowledgements Competing interests}

The author declares that he has no financial or personal relationship(s) that may have inappropriately influenced him in writing this article.

\section{References}

Anderson, M.D. \& Harris, G., 2011, 'Development of statewide freight plan for Alabama using integrated freight planning framework', in Commodity Flow Survey Workshop, November 16, 2010, Transportation Research Circular Number E-C158, Transportation Research Board, viewed 19 July 2012, from http://onlinepubs.trb. org/onlinepubs/circulars/ec158.pdf

Black, W., 1998, 'Commodity flow modeling', in W.R. Black, Transportation Research Board, Proceedings of the Statewide Travel Demand Forecasting Conference,
Irvine, CA, n.d., pp. 136-154, viewed 06 June 2013, from http://onlinepubs.trb. Irvine, CA, n.d., pp. 136-154, viewed $06 \mathrm{~J}$
org/onlinepubs/circulars/ec011/black.pdf

Chasomeris, M.G., 2003, 'South Africa's sea transport costs and port policy in a global context', Africana Bulletin 51, 133-63.

Curlee, T.R., 2006, 'Freight demand modeling: State of the practice within federal agencies', in K.L. Hancock (ed.), Freight Demand Modeling - Tools for Public-Sector Decision Making, Conference proceedings 40, Washington, USA, September 2527, 2006, pp. 24-25.

De Jong, G., Gunn, H. \& Walker, W., 2004, 'National and International Freight Transport Models: An Overview and Ideas for Future Development', Transport Reviews 24(1), 103-124. http://dx.doi.org/10.1080/0144164032000080494

Digre, B., Berndt, M. \& Bingham, P., 2011, 'Commodity flow survey findings in FAF2. 2 results and FAF3 update for Phase 2 of the I-70 dedicated truck lanes', in Commodity Flow Survey Workshop, November 16, 2010, Transportation Research Circular Number E-C158, Transportation Research Board, viewed 19 July 2012 from http://onlinepubs.trb.org/onlinepubs/circulars/ec158.pdf

Duych, R., 2011, 'What is new with the 2007 commodity flow survey?', Commodity Flow Survey Workshop, November 16, 2010, Transportation Research Circula Number E-C158, Transportation Research Board, viewed 19 July 2012, from http://onlinepubs.trb.org/onlinepubs/circulars/ec158.pdf

Global Security, 2013, 'Break Bulk Cargo', Global Security, viewed 04 March 2013 from http://www.globalsecurity.org/military/systems/ship/break-bulk-cargo.htm

Harris, G. \& Anderson, M.D., 2011, 'Using aggregated federal data to model freight in a medium-size community', in Commodity Flow Survey Workshop, November 16 , 2010, Transportation Research Circular Number E-C158, Transportation Research Board, viewed 19 July 2012, from http://onlinepubs.trb.org/onlinepubs/circulars/ ec158.pdf

Havenga, J.H., 2007, 'The development and application of a freight transport flow model for South Africa', PhD thesis, Dept. of Logistics Management, University of Stellenbosch.

Havenga, J.H., 2012, 'Rail renaissance based on strategic market segmentation principles', Southern African Business Review 16(1), 1-21.

Havenga, J.H. \& Pienaar, W.J., 2012a, 'Quantifying freight transport volumes in developing regions: Lessons learnt from South Africa's experience during the 20th century', Economic History of Developing Regions, 27(2), 87-113. http://dx.doi.or g/10.1080/20780389.2012.745666

Havenga, J.H. \& Pienaar, W.J., 2012b, 'The creation and application of a national freight flow model for South Africa', Journal of the South African Institution of Civil Engineering 54(1), 2-13.

Havenga, J.H., Pienaar, W.J. \& Simpson, Z., 2011, 'A case for measuring logistics costs on a national level: A South African application', Corporate Ownership and Control $8(3), 622-631$.

Havenga, J.H., Simpson, Z., Fourie, P.F. \& De Bod, A., 2011, 'Sustainable freight transport in South Africa: Domestic intermodal solutions', Journal of Transport and Supply Chain Management 5(1), 149-169.
Krygsman, S. 2006, Project notes for Transnet's commodity flow project, Dept. of Logistics, University of Stellenbosch.

Lawson, C., Nampoothiri, S. \& Peters, O.J., 2011, 'A freight data architecture application at the local level using commodity flow survey data', Commodity Flow Survey Workshop, November 16, 2010, Transportation Research Circular Number E-C158, Transportation Research Board, viewed 19 July 2012, from http://onlinepubs.trb. Transportation Research Board, view
org/onlinepubs/circulars/ec158.pdf

Liu, Q. \& Tolliver, D., 2011, 'How to utilize and improve commodity flow databases in national supply chain model', in Commodity Flow Survey Workshop, November 16, 2010, Transportation Research Circular Number E-C158, Transportation Research Board, viewed 19 July 2012, from http://onlinepubs.trb.org/onlinepubs/ circulars/ec158.pdf

Ludlow, D., 2011, 'Key observations on improving the 2007 commodity flow survey' Commodity Flow Survey Workshop, November 16, 2010, Transportation Research Circular Number E-C158, Transportation Research Board, viewed 19 July 2012 Circular Number E-C158, Transportation Research Board, viewed
from http://onlinepubs.trb.org/onlinepubs/circulars/ec158.pdf

Lyk-Jensen, S.V., 2011, 'Forecasting Freight Flows, Transport Reviews: A Transnationa Transdisciplinary Journal 31(5), 603-624.

McDonald, S. \& Punt, C., 2005, 'General equilibrium modelling in South Africa: What the future holds', Agrekon 44(1), 60-98. http://dx.doi.org/10.1080/03031853.2 the future hos 00523703

McKinnon, A., 2007, CO2 Emissions from Freight Transport in the UK Report prepared for the Climate Change Working Group of the Commission for Integrated Transport, Logistics Research Centre, Heriot-Watt University, Edinburgh.

McKinnon, A, \& Leonardi, J., 2008, 'The Collection of Long Distance Road Freight Data in Europe', in P. Bonnel, M. Lee-Gosselin, J. Zmud \& J.L. Madre (eds.), Transport Survey Methods: Keeping up with a Changing World, Emerald, United Kingdom.

Mesenbourg, T., 2011, 'The role of the commodity flow survey in understanding the U.S. economy', Commodity Flow Survey Workshop, November 16, 2010 , Transportation Research Circular Number E-C158, Transportation Research Board, viewed 19 July 2012, from http://onlinepubs.trb.org/onlinepubs/circulars/ec158. pdf

Mullins, D., 1977, 'Die moontlike impak van ' $n$ gedeeltelike of totale handelsboikot op die Suid-Afrikaanse ekonomie, met spesifieke verwysing na indiensname en inkome - 'n ondersoek gebaseer op die gebruik van statiese inset-uitsetanalise', inkome - ' $n$ ondersoek gebaseer op die gebruik
PhD thesis, University of the Orange Free State.

Panchalavarapu, P.R., 2010, 'What's the best design for your dedicated fleet?', CSCMP's Supply Chain Quarterly, Quarter 12010 , viewed 26 July 2012, from http://www.supplychainquarterly.com/print/scq201001dedicated/

Pretorius, W.P. 1991. 'Freight Transport Data Bank Report', 2nd edn. Research Unit for Transport Economic and Physical Distribution Studies, Rand Afrikaans University.

Raha, N. \& Williams, I., 2002, 'DfT Integrated Transport and Economic Appraisal: Review of Freight Modelling', a report, University of Westminster, London.

RAND Europe, 2001, 'Study on Ideas on a new National Freight Model System for Sweden: Report to the SAMGODS Group', RAND Europe and Transek AB, Leiden.

Rantasila, K. \& Ojala L., 2012, 'Measurement of National-Level Logistics Costs and Performance: Discussion paper 2012-04', Paris: International Transport Forum at the OECD.

Richard Paling Consulting, 2008, 'National Freight Demands Study', prepared for The Ministry of Transport, the Ministry of Economic Development and Land Transport New Zealand, September 2008, viewed 26 July 2012, from http://www.transport. govt.nz/research/Documents/FreightStudyComplete.pdf

Schwarm, W.R., Jackson, R.W. \& Okuyama, Y., 2006, 'An evaluation of method for constructing commodity by industry flow matrices', Journal of Regional Analysis and Policy 36(1), 84-93.

Smith, R.H.T., 1970, 'Concepts and Methods in Commodity Flow Analysis', Economic Geography 46, 404-416, Suppl. Proceedings, International Geographical Union Commission on Quantitative Methods. http://dx.doi.org/10.2307/143153

Sooredo, N., 2012, Historical TEU throughput, Drewry Publications, London.

Sprung, M., Southworth, F., Davidson, D., Hwang, H-L., Peterson, B., Chin, S-M., Vogt, D. \& Li, J-M., 2011, 'Overview of the FAF3 freight flow matrix construction process', Commodity Flow Survey Workshop, November 16, 2010, Transportation Research Circular Number E-C158, Transportation Research Board, viewed 19 July 2012, from http://onlinepubs.trb.org/onlinepubs/circulars/ec158.pdf

Transportation Research Board, 1997, 'A guidebook for forecasting freight transportation demand', NCHRP Report 388, National Academy Press, Washington DC, USA.

Van Eeden, J. \& Havenga, J.H., 2010, 'Identification of key target markets for intermodal freight transport solutions in South Africa', Journal of Transport and Supply Chain Management 4(1), 255-267.

Verburgh, C., 1958, 'Road transport of goods in South Africa', Bureau for Economic Research, Faculty of Commerce, University of Stellenbosch.

Zhang, Y., Bowden, R.O. \& Allen, A.J., 2003, 'Intermodal Freight Transportation Planning Using Commodity Flow Data - Final Report', Mississippi State University, Mississippi, viewed 24 July 2012, from http://citeseerx.ist.psu.edu/viewdoc/dow nload?doi=10.1.1.85.865\&rep=rep1\&type=pd 